\title{
ANALISIS MINAT INVESTOR DI KOTA SERANG TERHADAP INVESTASI SYARIAH
}

\section{PADA PASAR MODAL SYARIAH}

\author{
Hadi Peristiwo \\ IAIN Sultan Maulana Hasanuddin Banten
}

\begin{abstract}
Abstrak. Analisis Minat Investor Di Kota Serang Terhadap Investasi Syariah Pada Pasar Modal Syariah. Penelitian ini dilakukan dengan latar belakang bahwa untuk lebih mengenalkan dan mengembangkan pasar modal syariah, maka diperlukan adanya kekuatan suatu basis investor lokal (daerah) serta ketersediaan produk investasi syariah dalam jangka panjang. Kajian penelitian ini dilakukan terhadap investor yang yang berdomisili di Kota Serang Provinsi Banten. Metode penelitian yang digunakan dalam penelitian ini adalah dengan menggunakan metode analisis kuantitatif dengan menggunakan metode deskriptif yaitu data penelitian yang disajikan dalam bentuk grafik atau tabel. Analisis serta interpretasi lebih lanjut dilakukan atas faktor-faktor yang sangat berpengaruh signifikan terhadap minat investor untuk berinvestasi syariah. Terdapat 2 (dua) faktor yang paling menentukan (signifikan) terhadap minat investor untuk berinvestasi syariah. Pertama adalah kehalalan terhadap imbal hasil yang akan diperoleh dalam berinvestasi efek-efek syariah. Kedua adalah keyakinan bahwa efek syariah tidak bertentangan dengan prinsip syariah. Berdasarkan atas hasil serta analisis kajian penelitian yang telah dilakukan maka dapat disimpulkan bahwa sebagian besar investor di Kota Serang berminat untuk berinvestasi syariah pada pasar modal syariah.
\end{abstract}

Kata Kunci: minat investor, investasi syari'ah

Abstract. Analysis of Investor Interests toward Sharia Investments in Islamic Capital Market at Serang City. This research was conducted in order to introduce and develop the Islamic capital market. It needed the strength of local investors as well as the availability of Islamic investment products for the long term. This research conducted on investors domiciled in Serang City at Banten Province. The quantitative analysis method used in this research and descriptive method of research data presented in the form of graphs or tables. There are two (2) most decisive significant factors against the interest of investors to invest in sharia investment. Firstly, the earning in investment sharia securities is Halal. Secondly, the Islamic securities are not contrary to Islamic principles. Based on that results and analysis of the research, it can be concluded that the majority of investors in Serang City interested to invest in Islamic capital market.

Keywords: Investor interest, Islamic investment. 


\section{Latar Belakang Masalah}

Pasar modal syariah adalah suatu kegiatan ekonomi muamalah yang memperjualbelikan surat berharga yang menurut investasi syariah yaitu saham, obligasi dan reksadana syariah. Pasar modal syariah dikembangkan dalam rangka mengakomodir kebutuhan umat Islam di Indonesia yang ingin melakukan investasi di produk-produk pasar modal yang sesuai dengan prinsip dasar syariah. ${ }^{1}$ Penggunaan prinsip syariah di dalam pasar modal merupakan salah satu wujud kegiatan ibadah muamalah dan diharapkan memberi suatu solusi bagi masyarakat yang ingin menginvestasikan uangnya tanpa mengandung unsur riba dan ketidakadilan. ${ }^{2}$ Berkembangnya pasar modal syariah juga akan mengakomodir kebutuhan umat Islam di Indonesia yang ingin melakukan investasi di produk-produk pasar modal yang sesuai dengan prinsip dasar syariah. Dengan semakin beragamnya sarana dan produk investasi syariah, diharapkan masyarakat akan memiliki alternatif berinvestasi yang dianggap sesuai dengan keinginannya serta akan semakin memperbesar peran pasar modal syariah, disamping investasi yang selama ini sudah dikenal dan berkembang di salah satu sektor keuangan yaitu perbankan. ${ }^{3}$

Dalam rangka menjaga eksistensi dan menumbuh kembangkan pasar modal, diperlukan adanya kekuatan basis investor domestik dan ketersediaan investasi jangka panjang. Nilai investasi yang besar apabila hanya dimiliki oleh sedikit pihak maka akan kurang mendukung peningkatan basis investor domestik, sedangkan kekuatan basis investor domestik ditentukan oleh nilai investasi domestik dan jumlah investor domestik. ${ }^{4}$

Kota Serang sebagai wilayah baru hasil pemekaran Kabupaten Serang Provinsi Banten dengan jumlah populasi penduduk sebesar 672. 833 jiwa memiliki potensi yang cukup besar sebagai investor terhadap investasi syariah pada pasar modal syariah.

Permasalahan yang akan diangkat dalam penelitian ini adalah melakukan analisis serta identifikasi terhadap faktor-faktor yang mempengaruhi minat investor di Kota Serang untuk berinvestasi syariah pada pasar modal syariah.

Sesuai dengan identifikasi masalah yang diangkat dalam penelitian ini, maka penelitian ini bertujuan untuk mengetahui faktor-faktor yang signifikan dalam mempengaruhi minat investor di Kota Serang terhadap investasi syariah. Selanjutnya, 
Hadi Peristiwo: Analisis Minat Investor...

penelitian ini diharapkan dapat dijadikan bahan masukan bagi para praktisi pasar modal syariah untuk bertanggung-jawab terhadap kebijakan yang terkait dengan perkembangan pasar modal syariah khususnya dari sisi investor.

Dari penelitian ini diharapkan dapat memberikan manfaat/kontribusi yang positif diantaranya adalah:

a. Bahan pengambilan keputusan bagi investor di Kota Serang yang ingin berinvestasi khususnya investasi syariah

b. Tambahan informasi bagi peneliti untuk dapat lebih meningkatkan pengetahuan teori yang diperoleh pada keadaan yang terjadi sesungguhnya (practical)

c. Sebagai tambahan informasi/data untuk bahan penelitian selanjutnya

\section{Kerangka Konseptual}

Investasi berdasarkan konsep Islam sesungguhnya tidak berbeda dengan konsep konvensional secara filosofis. Investasi (konvensional) adalah pembelian sekuritas dan barang-barang yang tidak bergerak atau menyimpan dana sebagai modal kepada suatu perusahaan agar dari dana tersebut memberikan keuntungan secara berkesinambungan dan hasilnya menjadi hak milik investor.

Sedangkan konsep investasi menurut Islam (syari'ah) adalah entitas investasi yang berdasarkan prinsip-prinsip syari'ah, kehalalan investasi serta terhindar dari praktik-praktik riba, gharar dan maysir. ${ }^{5}$ Berbagai penelitian menunjukkan bahwa tingkat pengetahuan seseorang mengenai investasi seringkali menjadi faktor penentu di balik keputusan investasinya, terlepas apapun investasi yang dilakukannya. Investor yang memiliki tingkat pengetahuan keuangan (financial knowledge grade) yang lebih tinggi cenderung lebih baik dalam mengelola keuangan, termasuk dalam berinvestasi pada berbagai jenis produk finansial. Investor dengan pengetahuan keuangan yang lebih baik memiliki kecenderungan yang lebih besar untuk merencanakan investasi dalam menghadapi masa depan. 6 Berkaitan dengan investasi di pasar modal, investor yang lebih banyak memiliki pengetahuan dan pengalaman mengenai pasar modal, lebih besar kemungkinannya untuk dapat berinvestasi lebih besar di pasar modal. 


\section{Metode Penelitian}

Dalam rangka terlaksananya penelitian ini, maka perlu disusun suatu desain penelitian dalam suatu metodologi penelitian yang ilmiah. Dalam penelitian ini, metode pengumpulan data yang digunakan adalah kuisioner semi terstruktur (semi structured questionnaire). Metode yang akan digunakan oleh peneliti dalam penelitian ini yaitu metode analisis kuantitatif dengan menggunakan metode deskriptif, yaitu data penelitian yang akan disajikan dalam bentuk grafik dan tabel. Analisis serta interpretasi lebih lanjut dilakukan atas faktor-faktor yang sangat berpengaruh signifikan atas minat investor terhadap investasi syariah.

\section{Konsep Pasar Modal Syari'ah}

Menurut Undang-Undang Nomor 8 Tahun 1995 tentang Pasar Modal, definisi pasar modal adalah kegiatan yang berhubungan dengan penawaran umum dan perdagangan efek, perusahaan publik yang berkaitan dengan efek yang diterbitkannya, serta lembaga dan profesi yang berkaitan dengan efek.

Pasar modal merupakan salah satu alternatif sumber pendanaan bagi perusahaan sekaligus sebagai sarana investasi bagi para investor. Pelaksanaan dari hal tersebut adalah perusahaan dapat memperoleh pendanaan melalui penerbitan surat-surat berharga yang bersifat ekuitas atau surat hutang, sementara disisi lain investor dapat melakukan aktifitas investasi dipasar modal dengan membeli suratsurat berharga tersebut.

Secara kontekstual (umum) tidak terdapat perbedaan secara signifikan antara pasar modal konvensional dengan pasar modal syariah, karena pasar modal syariah merupakan bagian dari pasar modal, kecuali hal-hal yang menjadi larangan, baik didalam jenis efeknya maupun mekanisme transaksinya

\section{Perkembangan Investasi Syari'ah Pada Pasar Modal}

Sejak diluncurkannya reksadana syari'ah pertama kali, yaitu reksadana danareksa syari'ah pada tanggal 25 Juni 1997, perkembangan instrumen syari'ah terus mengalami perkembangan walaupun lambat namun pasti, mengalami kenaikan yang cukup signifikan. 
Hadi Peristiwo: Analisis Minat Investor...

Jika ditinjau dari jumlah penduduk Indonesia dan peningkatan jumlah penduduk kelas menengah kepada kelas atas, penduduk Indonesia memiliki potensi yang cukup signifikan sebagai investor di pasar modal.

Indonesia sendiri merupakan sebuah negara dengan penduduk yang mayoritas adalah beragama Islam, oleh karena itu industri pasar modal diharapkan dapat menjembatani dan sekaligus melibatkan peran serta dari masyarakat muslim untuk ikut aktif menjadi pelaku utama pasar terutama sebagai investor lokal di pasar modal. Hal tersebut diikuti oleh keinginan pemerintah yang bertekad untuk meningkatkan perekonomian makro termasuk juga ekonomi syari'ah, dimana diharapkan dapat berimbas terhadap sektor riil secara signifikan. ${ }^{7}$

\section{Bentuk-Bentuk Akad (Perjanjian) Dalam Islam}

Akad dalam bahasa Arab artinya perikatan atau perjanjian atau pemufakatan. Adapun pengertian berdasarkan fiqh maka akad adalah pertalian ijab (pernyataan melakukan ikatan) dan kabul (pernyataan menerima ikatan), sesuai dengan kehendak syariat yang berpengaruh pada objek perikatan.

Berdasarkan pengertian tersebut maka akad adalah suatu perbuatan hukum yang melibatkan kedua belah pihak atau lebih yang melakukan perjanjian. Ajaran Islam menekankan bahwa semua transaksi yang dilakukan oleh dua belah pihak atau lebih, tidak boleh menyimpang dan harus sejalan dengan syariat (hukum Islam).

Oleh karena itu akad menurut ajaran Islam adalah sesuatu yang penting. Hal ini disebabkan akad boleh dikatakan akan terjadi dalam setiap kegiatan yang ada hubungannya dengan muamalah. ${ }^{8}$ Para ulama mendeskripsikannya menjadi tukar menukar harta atas dasar saling ridha.

\section{Minat Investor Pada Efek Syariah}

Produk-produk investasi yang memenuhi prinsip-prinsip syariah saat ini berkembang semakin pesat dan menempati posisi yang semakin signifikan dalam perekonomian global.

Sejalan dengan globalisasi finansial, efek syariah yang semula banyak terdapat di kawasan Timur Tengah maupun Asia Tenggara kini banyak juga terdapat di berbagai belahan dunia, seperti di Eropa, Asia dan Amerika Serikat. 
Islamiconomic: Jurnal Ekonomi Keuangan dan Bisnis Islam Vol.7 No.1 Januari - Juni 2016

Namun demikian, salah satu hal yang menyebabkan pesatnya pertumbuhan efek syariah adalah minat yang semakin luas dikalangan investor muslim, terutama yang terdapat di negara-negara mayoritas muslim, untuk menanamkan modal mereka pada efek-efek yang sesuai dengan prinsip syariah.

Berbagai penelitian menunjukkan bahwa tingkat pengetahuan seorang mengenai investasi seringkali menjadi faktor penentu dibalik keputusan investasinya. Tingkat pemahaman seorang investor yang memiliki pengetahuan mengenai keuangan (financial literacy) yang lebih tinggi cenderung untuk lebih baik dalam mengelola keuangan, termasuk dalam berinvestasi pada berbagai jenis investasi yang bersifat produk finansial. Begitupun halnya bahwa seorang investor yang memiliki pengetahuan yang cukup mengenai pasar modal maka besar kemungkinannya investor tersebut untuk dapat berinvestasi di pasar modal.

\section{Peran Pasar Modal Syari'ah Dalam Pertumbuhan Ekonomi}

Pertumbuhan ekonomi (economic growth) senantiasa menjadi primadona dalam setiap proses pembangunan (development). Meskipun demikian, teori pembangunan yang diadopsi dari negara-negara maju untuk kemudian dikembangkan di negara-negara berkembang seringkali tidak mampu menjamin tercapainya kemakmuran rakyat sebagai tujuan utama pembangunan. Peranan pasar modal dalam kerangka pertumbuhan ekonomi suatu negara, dengan demikian menjadi jelas yaitu sebagai pembentukan modal (capital formation) yang menjadi penggerak utama berjalannya perekonomian setiap negara. Melalui pasar modal baik konvensional maupun syariah, investasi dalam negeri dan luar negeri dapat diserap sebagai modal penting dalam pembangunan dan pertumbuhan ekonomi.

\section{Ruang Lingkup Penelitian}

Ruang lingkup penelitian adalah investor yang berdomisili di Kota Serang Provinsi Banten. Dengan jumlah penduduk Kota Serang sebesar 618.802 orang yang tersebar dalam enam kecamatan, dengan kecamatan Serang sebagai Kecamatan dengan jumlah penduduk terbanyak sebesar 217.504 orang, sedangkan yang tersedikit penduduknya adalah Kecamatan Curug dengan jumlah penduduk sebesar 49.181 orang (tabel 1.1). 
Hadi Peristiwo: Analisis Minat Investor...

Tabel 1.1 Jumlah Penduduk Kota Serang Menurut Kecamatan

\begin{tabular}{|c|l|c|}
\hline No & \multicolumn{1}{|c|}{ Nama Kecamatan } & Jumlah Penduduk \\
\hline 1. & Curug & 49.181 \\
\hline 2. & Walantaka & 83.078 \\
\hline 3. & Cipocok Jaya & 93.081 \\
\hline 4. & Serang & 217.504 \\
\hline 5. & Taktakan & 84.106 \\
\hline 6. & Kasemen & 91.852 \\
\hline
\end{tabular}

Sumber: Badan Pusat Statistik (BPS) Kota Serang

Dilihat dari rasio indikator kependudukan, jumlah penduduk Kota Serang mengalami kenaikan setiap tahun (tabel 3.2), sehingga jumlah investor di Kota Serang pun mengalami peningkatan.

Tabel 1.2 Indikator Kependudukan

\begin{tabular}{|l|c|c|c|}
\hline \multicolumn{1}{|c|}{ Uraian } & Satuan & Tahun 2012 & $\begin{array}{c}\text { Tahun } \\
\mathbf{2 0 1 3}\end{array}$ \\
\hline Penduduk & Orang & 611.897 & 618.802 \\
\hline - Laki-Laki & Orang & 314.049 & 317.501 \\
\hline - Perempuan & Orang & 297.848 & 301.301 \\
\hline - Kepadatan Penduduk & Orang/Km2 & 2.294 & 2.320 \\
\hline Sex Ratio & - & 105 & 105 \\
\hline Dependency Ratio & $\%$ & 105 & 50,28 \\
\hline Komposisi Penduduk & & & \\
\hline - 0 - 14 tahun & $\%$ & 31,11 & 31,22 \\
\hline - 15 - 64 tahun & $\%$ & 66,54 & 66,39 \\
\hline - 65 tahun ke atas & $\%$ & 2,35 & 2,39 \\
\hline
\end{tabular}

Sumber: Badan Pusat Statistik (BPS) Kota Serang 
Islamiconomic: Jurnal Ekonomi Keuangan dan Bisnis Islam Vol.7 No.1 Januari - Juni 2016

Dalam penelitian ini, metode pengumpulan data yang digunakan adalah kuisioner semi terstruktur (semi structured questionnaire). Responden yang menjadi sasaran kuisioner ini adalah kuisioner individu. Kuisioner terdiri dari tiga bagian yaitu profil investor, pengetahuan investor mengenai investasi efek, serta minat investor terhadap efek syariah.

Peneliti membagi faktor-faktor yang mempengaruhi minat pada efek syariah kedalam faktor internal dan eksternal. Faktor internal antara lain meliputi kehalalan investasi, diversifikasi investasi, imbal hasil (return) investasi serta pengetahuan investor, sedangkan pada faktor eksternal diantaranya meliputi regulasi, kondisi ekonomi dan edukasi/sosialisasi tentang efek syariah.

Tujuan penelitian ini adalah untuk mempelajari minat investor di Kota Serang terhadap investasi syariah di pasar modal syari'ah. Metode yang akan digunakan oleh peneliti dalam penelitian ini adalah dengan menggunakan analisis kuantitatif dengan menggunakan metode deskriptif yaitu data disajikan dalam bentuk grafik dan tabel.

\section{Hasil dan Analisis Penelitian}

Penelitian yang dilakukan terfokus pada minat investor di Kota Serang terhadap investasi syariah pada pasar modal syari'ah. Total sampel investor dalam penelitian ini adalah sebanyak 100 responden yang tersebar di Kota Serang. Data yang digunakan adalah hasil pengkodingan dari jawaban pertanyaan kuesioner investor pada periode penelitian yaitu pada saat pertemuan investor (investor gathering) di Kota Serang. Dari total responden yang berjumlah 100 orang, semuanya di proses dan diolah lebih lanjut karena jawaban dari hasil kuisioner yang diberikan valid (lengkap).

Adapun secara garis besar, kuisioner disusun dengan sistematika sebagai berikut:

1. Lama Waktu Investor Investasi

Dalam pertanyaan ini diharapkan dapat memperoleh informasi mengenai lama waktu seorang investor dalam berinvestasi.

2. Jangka Waktu Berinvestasi

Dalam pertanyaan ini diharapkan dapat memperoleh informasi mengenai jangka waktu investor dalam berinvestasi. 
Hadi Peristiwo: Analisis Minat Investor...

3. Pengetahuan Investor

Dalam pertanyaan ini diharapkan dapat memperoleh informasi mengenai kedalaman (indeepth) pengetahuan investor mengenai investasi syariah di pasar modal syariah.

4. Minat Investor

Dalam pertanyaan ini diharapkan dapat memperoleh informasi mengenai seberapa besar minat investor dalam berinvestasi.

5. Faktor Internal

Dalam pertanyaan ini diharapkan dapat memperoleh informasi mengenai faktor-faktor internal yang menjadi bahan pertimbangan investor dalam berinvestasi

6. Faktor Eksternal

Dalam pertanyaan ini diharapkan dapat memperoleh informasi mengenai faktor-faktor eksternal yang menjadi bahan pertimbangan investor dalam berinvestasi

Dalam rangka mendapatkan informasi yang dapat dianggap mewakili seluruh bagian dari investor masyarakat di Kota Serang, maka penelitian ini dilakukan di 6 (enam) Kecamatan Kota Serang yaitu terdiri dari: Kec.Curug, Kec.Walantaka, Kec.Cipocok Jaya, Kec.Serang, Kec. Taktakan serta Kec. Kasemen. Investor yang menjadi responden adalah investor yang terdaftar (listed) sebagai investor pada Bursa Efek Indonesia (BEI) yang berdomisili di Kota Serang.

Dari hasil penyebaran kuisioner kepada responden yang berdomisili di Kota Serang maka didapatkan hasil dan analisis penelitian sebagai berikut: 


\section{Gambar 1.1 Lama Waktu Investor Investasi}

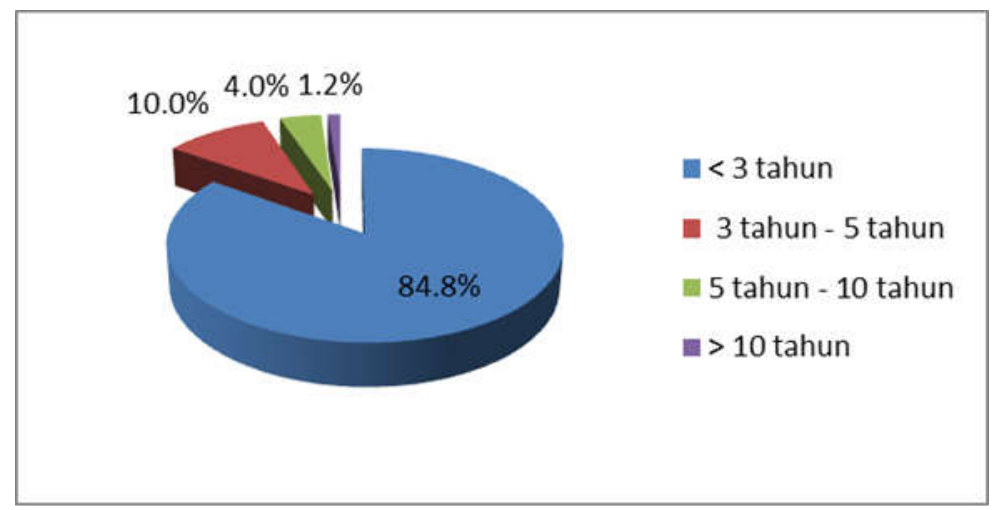

Dilihat dari lama nya waktu investasi, maka dari gambar 1.1 terlihat sekitar 84.8\% dari responden berinvestasi kurang dari 3 tahun, 10.0\% responden telah berinvestasi antara 3-5 tahun, sedangkan sebesar 4.0\% responden telah berinvestasi sekitar 5-10 tahun dan 1,2\% responden telah berinvestasi selama lebih dari 10 tahun.

\section{Gambar 1.2 Jangka Waktu Investasi}

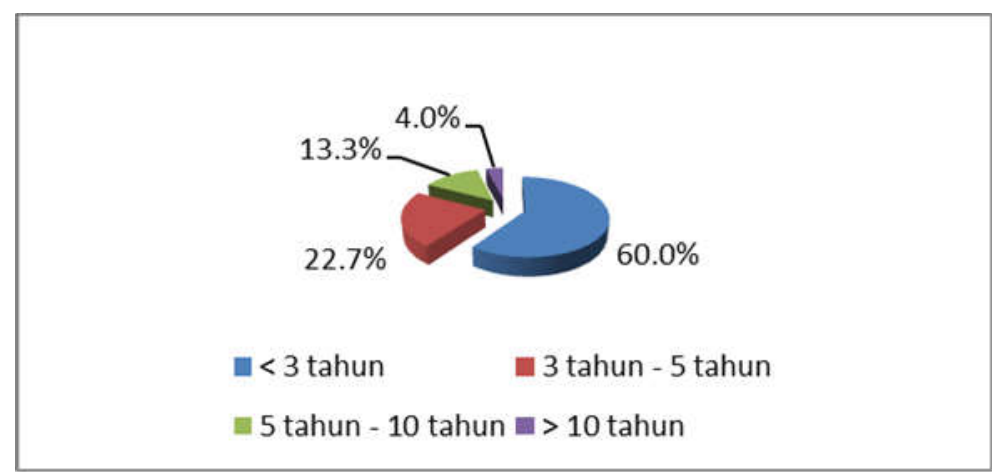

Dilihat dari jangka waktu investasinya, pada gambar 1.2 terlihat bahwa $60.0 \%$ responden menyatakan bahwa investor di Kota Serang memiliki rencana untuk berinvestasi dipasar modal syariah kurang dari 3 tahun, sebesar $22.7 \%$ dari responden memiliki rencana untuk berinvestasi selama 3-5 tahun, sedangkan sebesar 13.3\% memiliki rencana untuk berinvestasi selama 5-10 tahun sedangkan sebesar 4\% dari responden memiliki rencana untuk berinvestasi diatas 10 tahun. 


\section{Gambar 1.3 Pengetahuan Investor}

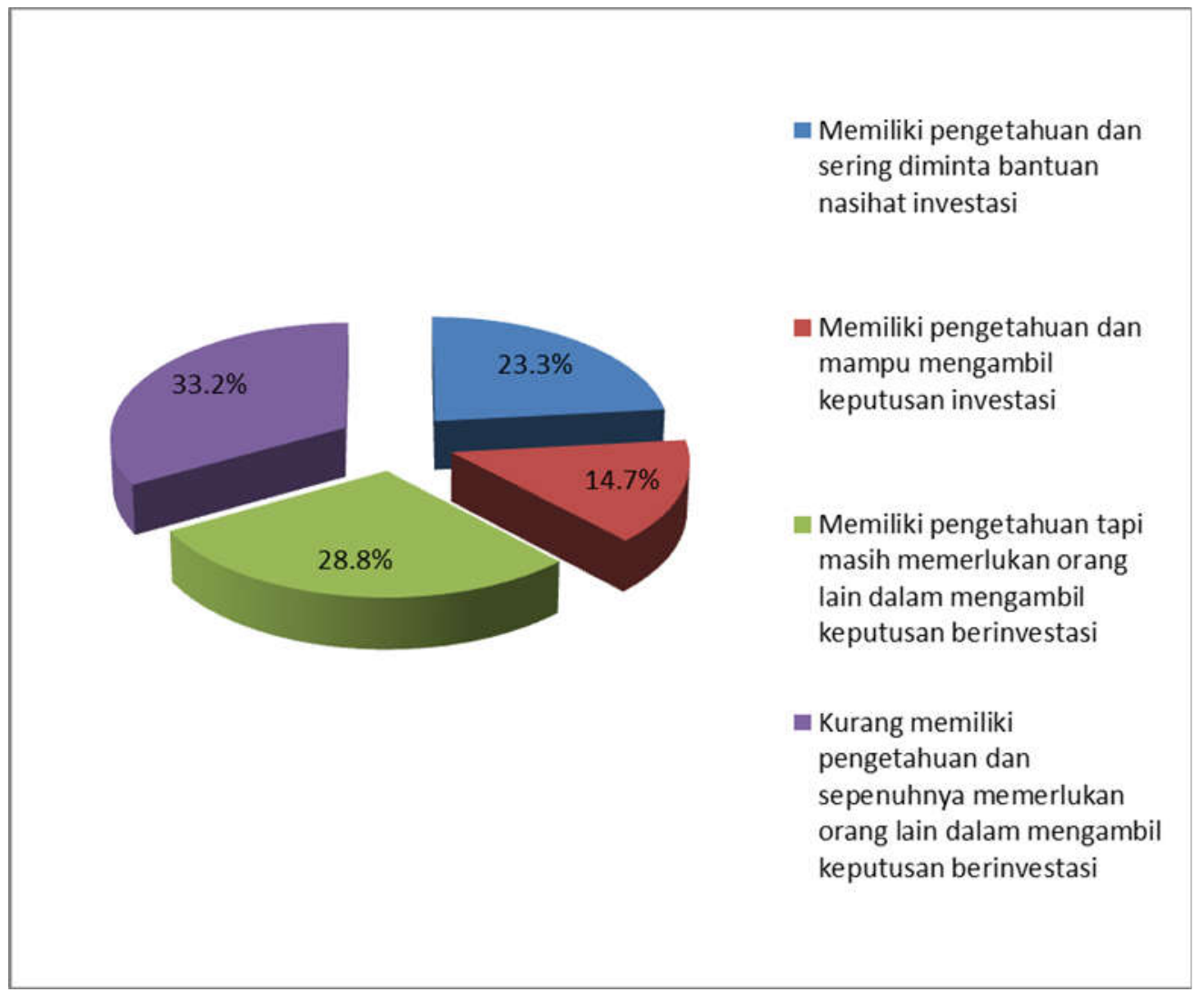

Dari hasil kuisioner, pada gambar 1.3 menunjukkan bahwa 23.3\% investor memiliki pengetahuan dan sering diminta bantuan nasihat investasi, sebesar $14.7 \%$ investor memiliki pengetahuan dan mampu mengambil keputusan investasi, sebesar 28.8\% investor memiliki pengetahuan tapi masih memerlukan orang lain dalam mengambil keputusan berinvestasi, sedangkan sebesar 33,2\% kurang memiliki pengetahuan dan sepenuhnya memerlukan orang lain dalam mengambil keputusan berinvestasi. 
Islamiconomic: Jurnal Ekonomi Keuangan dan Bisnis Islam Vol.7 No.1 Januari - Juni 2016

\section{Gambar 1.4 Minat Investor}

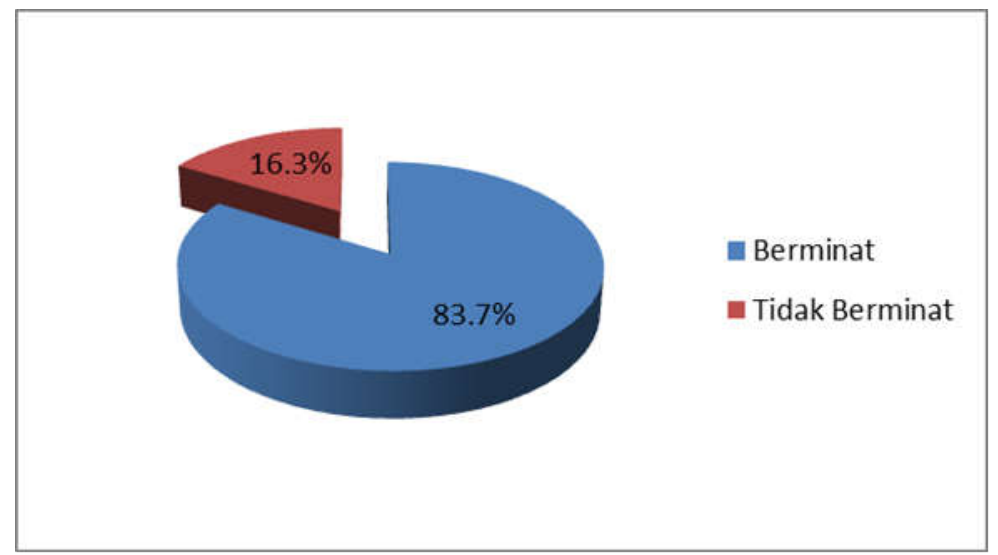

Dari hasil kuisioner yang diberikan kepada responden, menunjukkan bahwa investor di Kota Serang sebesar 83.7\% menyatakan ber-minat pada investasi syariah, sedangkan 16,3\% responden menyatakan tidak berminat pada investasi syariah.

\section{Gambar 1.5 Faktor Internal}

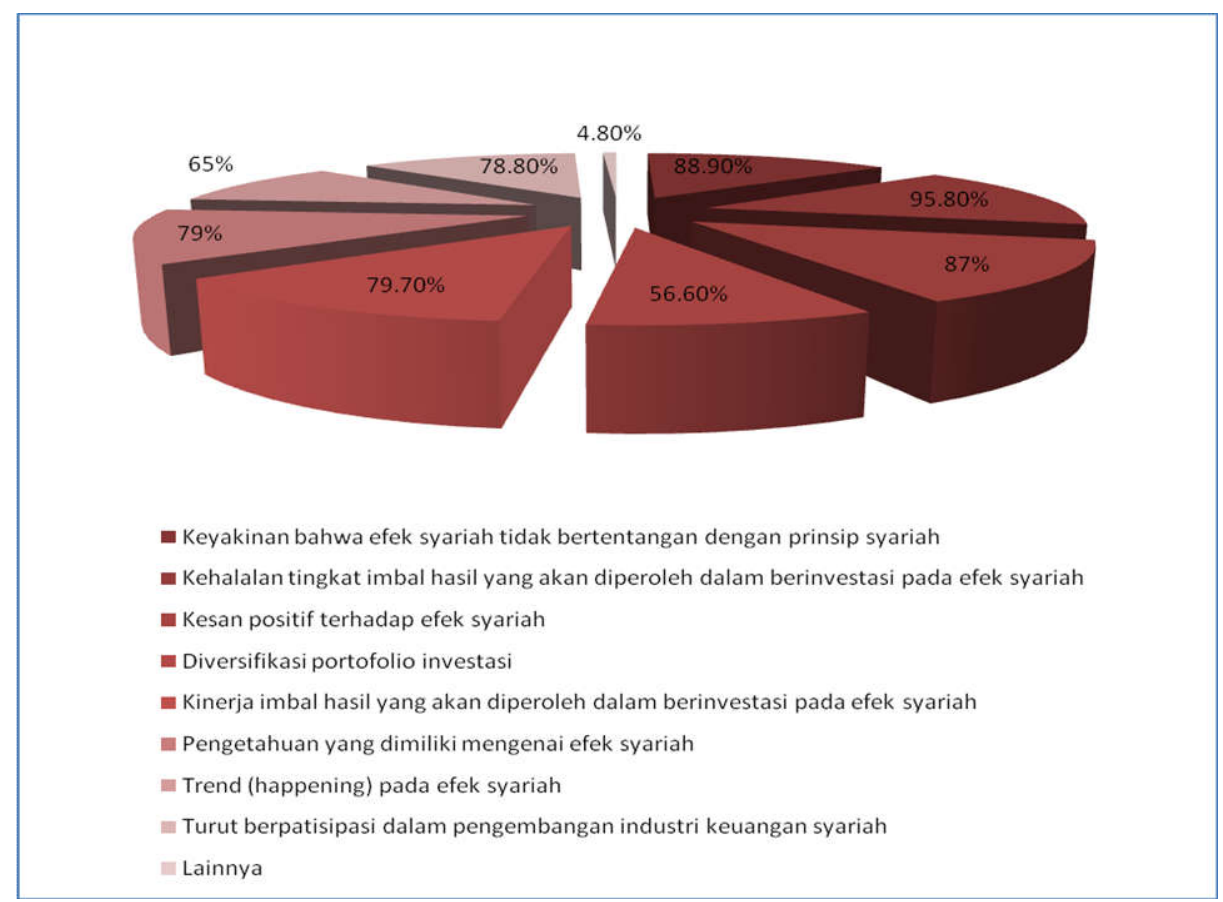


Hadi Peristiwo: Analisis Minat Investor...

Terdapat beberapa faktor internal yang dapat diketahui merupakan bagian yang dapat dipertimbangkan oleh investor di Kota Serang ketika berinvestasi syariah di pasar modal syariah.

Dari Gambar 1.5 menunjukkan bahwa faktor internal yang paling signifikan mempengaruhi minat investor berinvestasi syariah adalah kehalalan tingkat imbal hasil yang akan diperoleh dalam berinvestasi pada efek-efek syariah yaitu sebesar 95.80\%, kemudian sebesar 88.90\% menyatakan keyakinan bahwa efek syariah tidak bertentangan dengan prinsip syariah. Selanjutnya, responden juga menjawab sebesar 79.70\% menyatakan kinerja imbal hasil yang akan diperoleh dalam berinvestasi pada efek syariah, sebesar $87 \%$ menyatakan kesan positif terhadap efek syariah, sebesar 78.80\% menyatakan turut berpatisipasi dalam pengembangan industri keuangan syariah, kemudian sebesar 79\% mengenai pengetahuan yang dimiliki mengenai efek syariah, sebesar 65\% menyatakan trend (happening) pada efek syariah sedangkan $56.60 \%$ menyatakan diversifikasi portofolio investasi dan sebesar $4.80 \%$ menyatakan terdapat faktor-faktor internal lain yang berpengaruh terhadap minat investor dalam berinvestasi.

\section{Gambar 1.6 Faktor Eksternal}

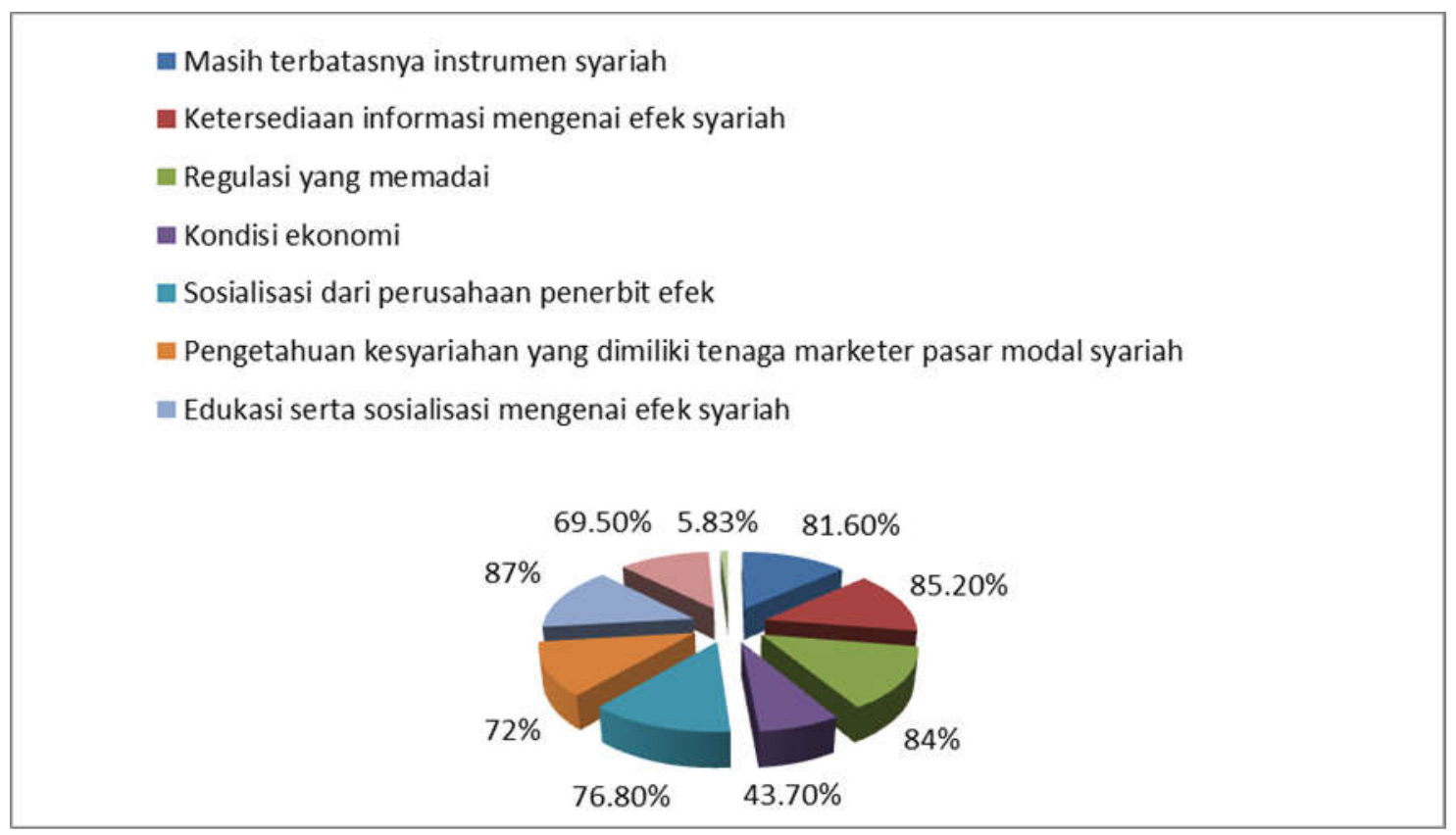


Gambar 1.6 menunjukkan bahwa faktor eksternal yang signifikan adalah edukasi serta sosialisasi mengenai efek syariah sebesar $87 \%$, kemudian ketersediaan informasi mengenai efek syariah sebesar $85.20 \%$, sebesar $84 \%$ menyatakan regulasi yang memadai, sebesar $81.60 \%$ menyatakan masih terbatasnya instrumen syariah, sebesar $76.80 \%$ menyatakan sosialisasi dari perusahaan penerbit efek, sebesar 69.50\% menyatakan adanya ketentuan yang mengatur untuk mengharuskan berinvestasi pada efek syariah, sebesar 43.70\% menyatakan kondisi ekonomi berkaitan dengan minat investor dalam berinvestasi dan sebesar $5.83 \%$ dari responden menyatakan terdapat faktor eksternal lain yang mempengaruhi minat investor dalam berinvestasi.

\section{Kesimpulan}

Berdasarkan atas hasil dan analis penelitian yang telah dilakukan, maka dengan ini dapat disimpulkan hal-hal sebagai berikut:

1. Sebagian investor yang berdomisili di Kota Serang berminat untuk berinvestasi syariah pada pasar modal syariah. Faktor yang signifikan terhadap minatnya investor untuk berinvestasi adalah kehalalan tingkat imbal hasil yang akan diperoleh ketika berinvestasi pada efek-efek syariah.

2. Bagi investor yang tidak berminat pada investasi syariah, lebih dikarenakan oleh faktor kurangnya edukasi dan sosialisasi mengenai efek syariah serta masih terbatasnya instrumen syariah pada pasar modal syariah.

\section{Rekomendasi}

Berdasarkan pembahasan dan kesimpulan yang telah diuraikan, maka direkomendasikan hal-hal sebagai berikut :

1. Perlu dilakukan peningkatan pengetahuan serta pemahaman mengenai produk-produk efek syariah kepada investor dan calon investor yang ingin berinvestasi secara syariah

2. Menetapkan suatu kebijakan mengenai ketentuan yang mengatur untuk mengharuskan berinvestasi pada efek syariah 
Hadi Peristiwo: Analisis Minat Investor...

Dengan melakukan kegiatan tersebut, maka diharapkan para investor serta calon investor yang tidak memiliki minat sebelumnya untuk berinvestasi secara syariah dapat tertarik untuk memiliki minat berinvestasi syariah pada pasar modal syariah.

\section{Pustaka Acuan}

Badan Pengawas Pasar Modal dan Lembaga Keuangan, Master Plan Pasar Modal dan Industri Keuangan Non Bank 2010-2014, Kementerian Keuangan Republik Indonesia

Heykal, Mohammad, Tuntunan dan Aplikasi Investasi Syariah, Jakarta: PT. Elex Media Komputindo, 2012

Huda, Nurul dan Mustafa Edwin Nasution, Investasi Pada Pasar Modal Syari'ah, Jakarta : Kencana Prenada Media Group, 2007

Ismail, Keuangan dan Investasi Syariah (Sebuah Analisa Ekonomi), Jakarta: Sketsa, 2010

Masyarakat Ekonomi Syariah (MES) Pekalongan, Ekonomi Syariah (Konsep, Praktek \& Penguatan Kelembagaannya), Semarang: Pustaka Rizki Putra, 2009

Sutedi, Adrian, Pasar Modal Syariah (Sarana Investasi Keuangan Berdasarkan Prinsip Syariah), Jakarta: Sinar Grafika, 2011

Suwandi, Kuntjoro, Panduan Cerdas Investasi, Yogyakarta: Pinang Merah Publisher, 2011

Syafei, Rahmat, Fiqih Muamalah, Bandung : Pustaka Setia, 2004

Wahyu, Sigit, Perkembangan Pasar Modal Syari'ah, Jakarta : PEBS-FEUI, 2007

Widoatmodjo, Sawidji, Pasar Modal Indonesia (Pengantar \& Studi Kasus), Bogor: Penerbit Ghalia Indonesia, 2009

\section{Catatan Akhir:}

\footnotetext{
${ }^{1}$ Sutedi, Adrian, Pasar Modal Syariah (Sarana Investasi Keuangan Berdasarkan Prinsip Syariah), Jakarta: Sinar Grafika, 2011

${ }^{2}$ Ismail, Keuangan dan Investasi Syariah (Sebuah Analisa Ekonomi), Jakarta: Sketsa, 2010

${ }^{3}$ Masyarakat Ekonomi Syariah (MES) Pekalongan, Ekonomi Syariah (Konsep, Praktek \& Penguatan Kelembagaannya), Semarang: Pustaka Rizki Putra, 2009

${ }^{4}$ Badan Pengawas Pasar Modal dan Lembaga Keuangan, Master Plan Pasar Modal dan Industri Keuangan Non Bank 2010-2014, Kementerian Keuangan Republik Indonesia

${ }^{5}$ Heykal, Mohammad, Tuntunan dan Aplikasi Investasi Syariah, Jakarta: PT. Elex Media Komputindo, 2012
} 
Islamiconomic: Jurnal Ekonomi Keuangan dan Bisnis Islam Vol.7 No.1 Januari - Juni 2016

${ }^{6}$ Suwandi, Kuntjoro, Panduan Cerdas Investasi, Yogyakarta: Pinang Merah Publisher, 2011

${ }^{7}$ Wahyu, Sigit, Perkembangan Pasar Modal Syari'ah, Jakarta : PEBS-FEUI, 2007

${ }^{8}$ Syafei, Rahmat, Fiqih Muamalah, Bandung : Pustaka Setia, 2004 